\title{
EFFECT OF VOLCANIC ASH-FALL ON A PERMIAN PEAT-FORMING ENVIRONMENT, ON THE BASIS OF PALYNOLOGY, PALYNOFACIES AND PALEOBOTANY (FAXINAL COALFIELD, BRAZIL)
}

\author{
MIRIAM CAZZULO-KLEPZIG \\ Departamento de Paleontologia e Estratigrafia, IGEO, UFRGS, Av. Bento Gonçalves, \\ 9500, Cx. P. 15001, 91501-970, Porto Alegre, RS, Brasil.miriam.klepzig@ ufrgs.br \\ JOÃO GRACIANO MENDONÇA FILHO \\ Laboratório de Palinofácies e Fácies Orgânica, IGEO, UFRJ, Ilha do Fundão, 21941-916, Rio de Janeiro, RJ, Brasil. \\ MARGOT GUERRA-SOMMER \\ Departamento de Paleontologia e Estratigrafia, IGEO, UFRGS, Av. Bento Gonçalves, \\ 9500, Cx. P. 15001, 91501-970, Porto Alegre, RS, Brasil. \\ TAÍSSA REGO MENEZES \\ CENPES , PETROBRÁS , Cidade Universitária, Ilha do Fundão, 21941-598, Rio de Janeiro, RJ, Brasil. \\ MARGARETE WAGNER SIMAS \\ Programa de Pós-graduação em Geociências, IGEO, UFRGS, Av. Bento Gonçalves, \\ 9500, Cx. P. 15001, 91501-970, Porto Alegre, RS, Brasil. \\ JOALICE OLIVEIRA MENDONÇA \\ Laboratório de Palinofácies e Fácies Orgânica, IGEO, UFRJ, Ilha do Fundão, 21941-916, Rio de Janeiro, RJ, Brasil. \\ ISABELA DEGANI-SCHMIDT \\ Programa de Pós-graduação em Geociências, IGEO, UFRGS, Av. Bento Gonçalves, \\ 9500, Cx. P. 15001, 91501-970, Porto Alegre, RS, Brasil.
}

\begin{abstract}
The aim of this paper was to assess, in a study case, whether ash-fall deposition influenced the character of the peat-forming vegetation in some coal beds in the southernmost Paraná Basin in Brazil, taking into consideration that records of tonstein levels are common in some coal bearing-strata. An investigation was made of the uppermost Faxinal coal seam (Coal Seam S), which displays two adjacent coal beds interbedded with a tonstein level. On the basis of the botanical affinity between the miospores and the parent plants as well as the relative abundance of the different plant groups, each coal plant assemblage was determined. Furthermore, previous paleobotanical data obtained on the tonstein level that identified a compressed Glossopteris flora were incorporated in the study. Palynofacies analyses performed on both coal and tonstein levels demonstrated good results for the recognition of preserved organic matter and changes in paleoenvironmental conditions along the coal sequence. The effect of volcanic ash-fall deposition was reflected by changes in the character of the vegetation associated with coal layers below and above the tonstein. Palynofacies results corroborated palynological and paleobotanical interpretation and contributed to the establishment of the floral succession deposited over a short time interval, under the effect of volcanic ash-fall deposition.
\end{abstract}

Key words: palynology, paleobotany, palynofacies, coal, tonstein, Paraná Basin.

RESUMO - O trabalho objetivou avaliar o efeito da deposição de cinza vulcânica sobre o caráter da vegetação responsável pela formação de alguns carvões na jazida do Faxinal, levando em consideração que registros de tonstein são comuns em sequências de carvão na porção sul da bacia do Paraná, no Brasil. Em estudo de caso, foi analisada a camada de carvão superior (Camada S) que apresenta, na sua porção mais superior, dois leitos adjacentes de carvão intercalados por um nível de tonstein originado de cinza vulcânica. A composição das palinofloras foi determinada com base na afinidade dos esporos e dos grãos de pólen e na relação de freqüência dos diferentes grupos vegetais. Dados paleobotânicos anteriores desenvolvidos nesse nível de tonstein, que demonstraram a presença de uma importante Flora Glossopteris, foram incorporados ao trabalho aqui proposto. As análises de palinofácies produziram resultados significativos para o reconhecimento da matéria 
orgânica preservada tanto nos carvões como no tonstein e das variações nas condições do paleoambiente, ao longo da sucessão de carvão. Análises de palinofácies desenvolvidas tanto sobre os carvões como sobre o tonstein demonstraram bons resultados para o reconhecimento da matéria orgânica preservada e de mudanças nas condições paleoambientais ao longo da sequência de carvão. O efeito de deposição de cinza vulcânica refletiu-se claramente nas variações do caráter da vegetação relacionada aos níveis inferior e superior de carvão. Os resultados de palinofácies corroboraram a interpretação palinológica e paleobotânica, demonstrando modificações na composição florística ao longo dessa sucessão, que foi depositada em curto intervalo de tempo, sob efeito da deposição de cinza vulcânica.

Palavras-chave: palinologia, paleobotânica, palinofácies, carvão, tonstein, bacia do Paraná.

\section{INTRODUCTION}

The coal-bearing strata in the southernmost Paraná Basin are part of the southeastern outcrop belt of the Rio Bonito Formation which integrates, according to Holz et al. (2002), part of two third-order depositional sequences of the Carboniferous-Early Triassic second-order sequence, called S2 and S3. In Rio Grande do Sul State, most of the coals occur within the transgressive systems tract of Sequence 2, as detailed by Holz (1998) and Holz et al. (2000).

Extensive paleobotanical, palynological and sedimentological studies on the southernmost Brazilian coals have demonstrated, in a general way, a close compositional similarity of the floras from different coal seams (MarquesToigo \& Corrêa da Silva, 1984; Guerra-Sommer et al., 1991; Cazzulo-Klepzig, 2002). The results indicate the presence of hypautochthonous coals which were recognized by palynological composition and accumulation of peat retarded during drier intervals, according to the concepts of Glasspool (2003). The coals were generated by peat-forming floras characterized by the same basic plant groups, with minor variations. However, relative dominance-diversity patterns and species composition differed between the different coal seams. In general, the microfloras are characterized by the dominance of pteridophytic spores derived from shrub-like and arborescent vegetation (mainly lycopsids, filicopsids and sphenopsids) and lower representation of pollen grains of gymnospermic plants (glossopterids, Cordaites and conifers). Otherwise, the presence of algae and algae-like forms has been mentioned as a common feature in these coal palynofloras (Cazzulo-Klepzig, 2001).

However, for the Faxinal coal-bearing strata, the focus of the present study, prior paleobotanical and palynological studies conducted by Guerra-Sommer et al. (1984), which included the coals and a tonstein layer interbedded in the uppermost coal seam (Coal Seam S in Figure 1), referred to significant compositional differences in the peat coal-forming flora in relation to other floras previously recognized for the south Brazilian coal seams, although all the coals were considered hypautochthonous coals. Furthermore, for the tonstein layer interbedded in the uppermost Faxinal coal seam, an important compressed Glossopteris flora was described by Guerra-Sommer (1988, 1992). This autochthonous flora is composed of leaves, branches and reproductive structures of glossopterids, leaves of Cordaites and filicoid fronds.
Previous palynological results from the Faxinal coals obtained by Dias \& Guerra-Sommer (1994) for the whole uppermost coal seam mentioned, in a preliminary analysis, a poorly diversified palynoflora, composed of spores produced by a pteridophytic plant community with a dominance of lycopsids and filicopsids which are followed by pollen grains of pteridosperms, Cordaites and conifers as well as algaelike forms. However, these data contrasted with more recent results obtained by Cazzulo-Klepzig et al. (2007). In detailed palynological analyses, the authors mentioned that in Faxinal coals, mainly in the uppermost coal seam (Coal Seam S), palynoassemblages are marked by the dominance of bisaccate (striate and non-striate) and monosaccate pollen grains related to glossopterids, conifers and Cordaites. These pollen grains are followed by a low proportion of spores of lycopsids, filicopsids and scarce sphenopsids, which points out the minor contribution of pteridophytic plants to the peat coalforming vegetation, in contrast to the majority of palynofloras recognized for the southernmost Brazilian coals. Otherwise, there was a minor presence of algal elements (incertae sedis) or acritarchs (Maculatasporites and Portalites). In addition, paleobotanical analyses of Guerra-Sommer et al. (1984) identified for the same coal seam some dispersed wood fragments, tracheids and epidermal cuticles related to glossopteridales. Besides these mega- and microfloristic data, petrological results obtained by Henz (1986) on the basis of petrographical and chemical analyses pointed out for this coal seam the presence of a maceral group with a dominance of vitrinite (mainly vitrite) and low amount of the exinite and inertinite groups. Based on these results, the author also interpreted for these coals a peat-forming vegetation dominated by arborescent plants, corroborating palynological and paleobotanical interpretation.

These particular paleobotanical and paleoecological characters of the Faxinal coal-forming floras suggest, according to the authors, that the compositional differences, mainly in quantitative terms, may have originated from particular paleoenvironmental conditions. Therefore, these particular conditions could be inferred based on the record of an important megaflora showing leaves and other fragments of glossopterids, Cordaites and sphenopterids well-preserved in claystone levels interbedded in the uppermost coal seam (Guerra-Sommer, 1988).

As the peats, in a general way, yield information on the changes of vegetation in the mire and in the surrounding vegetation through palynomorphs (Hughes \& DuMayne- 
Peaty, 2002), it is possible to obtain, through the palynological content, insight into the flora composition which can be a good control for the interpretation of palynofloras from the same coals.

Based on palynological, paleobotanic and paleoecological criteria, a reconstruction of landscape units and peat-forming plant communities for the peat mires in southernmost Brazil was tentatively outlined by CazzuloKlepzig (2002) and Cazzulo-Klepzig et al. (2007). For the Faxinal coal formation, the authors suggested, based on the peculiar characteristics of the micro- and megafloristic content, a particular scenario for the placement of the peatforming environment, in contrast to the scenario previously suggested for peat accumulation in other southern Brazilian coals (Cazzulo-Klepzig, 2001).

Therefore, it is important to highlight the evidence of volcanic activity recorded for the south Brazilian coal-bearing strata, mainly in the Candiota and Faxinal coalfields (Formoso et al., 1999; Matos et al., 2001; Cazzulo-Klepzig et al., 2005; Guerra-Sommer et al., 2008a,b,c; Simas, 2008; Simas et al., 2009). The volcanic rocks, identified as tonsteins, are represented by discrete and continuous horizons of clay beds interbedded within different coal seams. According to most literature sources, under conditions favorable to coal formation, tuffs are converted into tonsteins.

Hudle \& Englund (1966) reported that tonsteins are excellent time markers for stratigraphic and basin analyses, corresponding to units deposited during a limited period of time. Creech (2002) pointed out the importance of tonsteins in correlating different coal seams with those stratigraphically equivalent in adjacent coalfields, so that radiometric data supplied by tonstein layers facilitate their application as isochronous markers in coal bearing-strata.

Considering that U/Pb SHRIMP age determination in zircons from tonstein indicated a near contemporaneous time interval for coal formation in both different coal successions, the floristic compositional differences between these coal seams were considered as representing only local paleoenvironmental conditions, with no stratigraphic significance (Guerra-Sommer et al., 2008a,b,c), in contrast to previous conceptions of Guerra-Sommer et al. (2006). This interpretation is in accordance with the model presented by Pfefferkorn \& Wang (2007) for some peat-forming plant communities in the Permian of Mongolia and China, which shows a great variability of vegetation and landscapes over a geologically short time span.

Taking into account important characteristics identified in the uppermost Coal Seam S, such as the patterns of floristic changes across the coal accumulation phase and the important compressed flora (Glossopteris Flora) preserved in the tonstein level (Guerra-Sommer et al., 2006, 2008a,b,c), and recent data from Jasper et al. (2009) recording the presence of charcoal in this tonstein, the aim of the present study was to estimate, in a study case, the persistence of paleoecological conditions over a geologically short time span and to evaluate the effect of ash-fall deposition on coalforming plants. According to Crowley et al. (1994), the water in peat mire often increased after deposition of volcanic ash, and palynological analysis could contribute significantly to determining if volcanic ash-fall affected the peat-forming vegetation in the mires, which formed the coals (Williams, 1992).

Furthermore, considering that palynofacies methods constitute an important tool for paleoenvironmental reconstruction and can improve the recognition of geochemical changes in the preserved organic matter through the identification of phytoclasts, amorphous organic matter and palynomorphs (Gastaldo et al., 1994), results from palynofacies analyses were incorporated into the present study. In the literature, few studies so far have employed palynofacies analyses as a tool to interpret paleoecological conditions controlling the process of coal formation.

\section{GEOLOGICAL AND STRATIGRAPHICAL SETTING}

The Paraná Basin is a large intracratonic basin (1.400.000 $\mathrm{km}^{2}$ ) covering part of Uruguay, Argentina, Paraguay and southern Brazil. Basin floor subsidence, in addition to Paleozoic sea level changes, created six second-order sequences deposited from the Ordovician to the Late Cretaceous, separated by regional unconformities (Milani et al., 1998).

In Rio Grande do Sul State, according to Holz (1998) and Holz et al. (2000, 2002), most of the coals occur within a transgressive systems tract of Sequence 2, linked to swamps and marshes in a lagoonal/estuary setting.

The Faxinal coalfield (Figure 1), mined by the Companhia de Pesquisas e Lavras Minerais (COPELMI), is located near the town of Arroio dos Ratos, about $120 \mathrm{~km}$ southwest of Porto Alegre (UTM N432.7/E6651.5) and contains 3.50 million tons of coal reserves. It is located close to the Água Boa and Sul do Leão coalfields, in a graben, previously referred as the Leão/Mariana Pimentel paleovalley (Ribeiro et al., 1987), which is an elongate structure trending SE-NW in its eastern portion and E-W to the west. The graben, inserted in the basement, is $60 \mathrm{~km}$ long and up to $5 \mathrm{~km}$ wide. The three coalfields are downthrown structural blocks, mainly controlled by a $\mathrm{N} 40^{\circ} \mathrm{E}$ fault system, and their extent is limited by subsequent erosion. The Faxinal coalfield is situated in the eastern part of the graben and includes five coal seams, named from the base to top as: I, IM, M, MS and S. The seams are interbedded with siltstones, claystones, sandstones and paleosoils.

The present study focuses on the whole uppermost Coal Seam S, of approximately $2.10 \mathrm{~m}$ thick, including two coal beds, the lower being $0.60 \mathrm{~m}$ and the upper $1.40 \mathrm{~m}$, interbedded with a light gray clay bed of approximately $0.10 \mathrm{~m}$ thick, identified as a tonstein layer (Figure 2: levels $\mathrm{a}, \mathrm{b}$ and $\mathrm{c})$. 


\section{MATERIALS AND METHODS}

\section{Palynology: sampling and analytical procedures}

For the palynological analyses, samples were collected from two adjacent coal beds and from the interbedded tonstein layer in the uppermost Coal Seam S (Figure 2: levels a, b and c). Samples were processed in Schulze Solution (65\% nitric acid; $\left.\mathrm{HNO}_{3}\right)$, saturated with potassium chloride $\left(\mathrm{KClO}_{3}\right)$ and neutralized in potassium hydroxide $(\mathrm{KOH})$, enabling the rapid maceration of the palynomorphs. A total of 200 miospores were counted from each sample to determine the relative proportions of miospore taxa, following the method of percentage frequency cited by de Jekhowsky (1963). Assignments of dispersed spores and pollen grains to their respective parent plant groups were based on the compilations of Balme (1995), Gould \& Delevoryas (1977) and Quadros et al. (1995).

Cuticular and dispersed wood analyses were based on the same slides used for palynological studies, focusing on the notable fragments of epidermal fragments and other plant debris.

\section{Palynofacies: sampling and analytical procedures}

For palynofacies studies, samples were collected from the different cutbanks of the open pit areas aiming to compare the distribution of the particulate organic matter (POM) along the succession coal profile. In the coals, six levels were considered for the study, three of them corresponding to the coal bed below the tonstein and the other one to the coal bed above it. In the tonstein, three different levels were analyzed independently, corresponding to the basal, intermediate and top levels (detailed in Simas et al., 2009).

Samples were first treated with $\mathrm{HCl}$ and $\mathrm{HF}$ followed by heavy liquid $\left(\mathrm{ZnCl}_{2}\right)$, in order to concentrate the organic matter. The isolated organic matter was then mounted on strewn slides. The preparation technique employed was the standard non-oxidative palynological procedure.

Sample preparation for isolated kerogen. The concentrated organic matter was prepared using the standard procedure described by Menezes et al. (2008). It is believed that the about thirty-forty grams per sample provides enough residue.

Palynofacies analysis was carried out to evaluate the content of particulate organic matter in coal seam and tonstein. The microscopy method combined the use of transmitted white light and blue light/UV fluorescence techniques (Tyson, 1995).

The palynofacies technique involved the qualitative and quantitative assessment of the total organic matter comprising the identification of all particulate organic matter constituents and their size, preservation state and relative proportions. The relative percentage of these components is based on counting at least 300 particles per slide (Mendonça Filho, 1999). AZeiss microscope (AXIOSKOP 2 PLUS model with 10x oculars and 20x objective) was used to count the particles in each sample.

Kerogen classification. The particulate organic matter (kerogen) present in sedimentary rock has various definitions (e.g., Staplin, 1969; Combaz, 1980; Whitacker, 1984). The kerogen classification used in this study was modified and

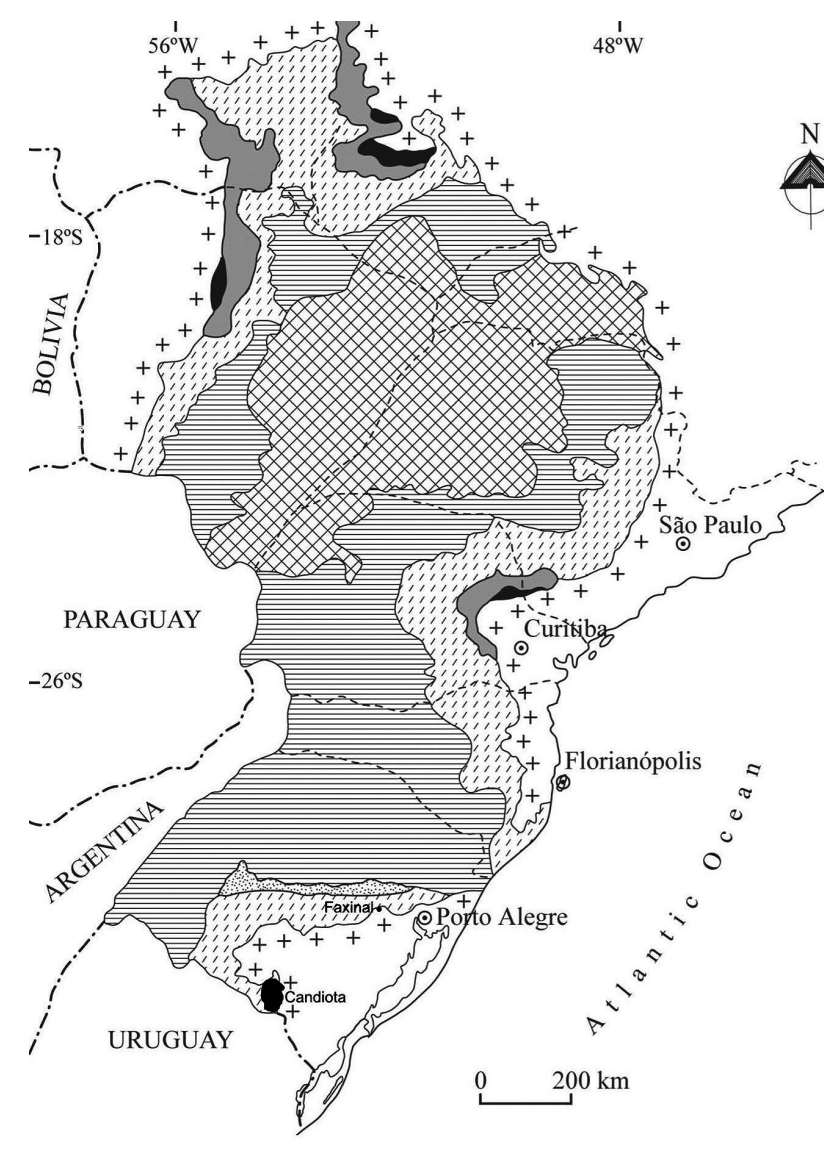

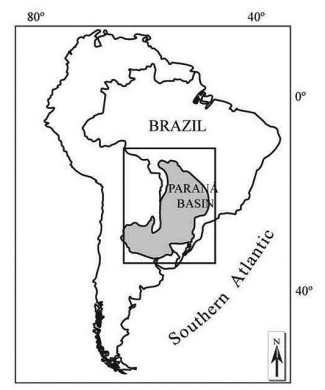

LEGEND

Bauru Supersequence (Cretaceous)

Gondwana III Supersequence (Jurassic/Cretaceous)

Gondwana II Supersequence (Triassic)

Gondwana I Supersequence (Carboniferous/Permian)

Paraná Supersequence (Devonian)

Rio Ivaí Supersequence (Ordovician/Silurian)

Precambrian Basement (boundary of the basin)

Boundary between Brazilian States

-.. International frontiers

- Coalfield

๑ Main cities

Figure 1. Location map of the study area (from Simas et al., 2009). 
extended from Tyson (1995), Mendonça Filho (1999) and Mendonça Filho et al. (2002).

The kerogen assemblage is arranged in three main groups of morphological constituents: phytoclast (a continental fraction derived from macrophyte tissue flora), AOM (reworked bacterial derived) and palynomorph (continental fraction including pollen grains, spores and freshwater algae, marine components and zoomorphs).

Graphic representation of the relative abundance of the main components in each coal bed and tonstein was prepared (Figures 11-12).

\section{RESULTS}

Although palynological and palynofacies results obtained for both coal beds show a certain similarity between them, mainly in terms of the qualitative composition, important floristic changes were detected, mainly in the coal bed above the tonstein, which shows a weak presence of pteridophytic vegetation (Figure 2).

\section{Coal bed below the tonstein}

Palynology. Palynological analyses demonstrated abundant and well-preserved palynomorphs showing a dominance of trilete spores related to pteridophytic vegetation. Arborescent lycopsids are represented by Lundbladispora (approximately $22 \%$ of the whole palynological assemblage) while herbaceous lycopsids are evidenced by the presence of Vallatisporites, Cristatisporites, Kraeuselisporites, making up approximately 19\%. Forms of Apiculatisporis, Cyclogranisporites, Horriditriletes, Granulatisporites, Punctatisporites, Leiotriletes and Convolutispora (6\%) reflect the presence of filicopsids. Scarce sphenopsids (2\%) are represented by Calamospora and Retusotriletes. This coal palynoflora shows a compositional similarity to that previously recognized for the southernmost Paraná Basin in

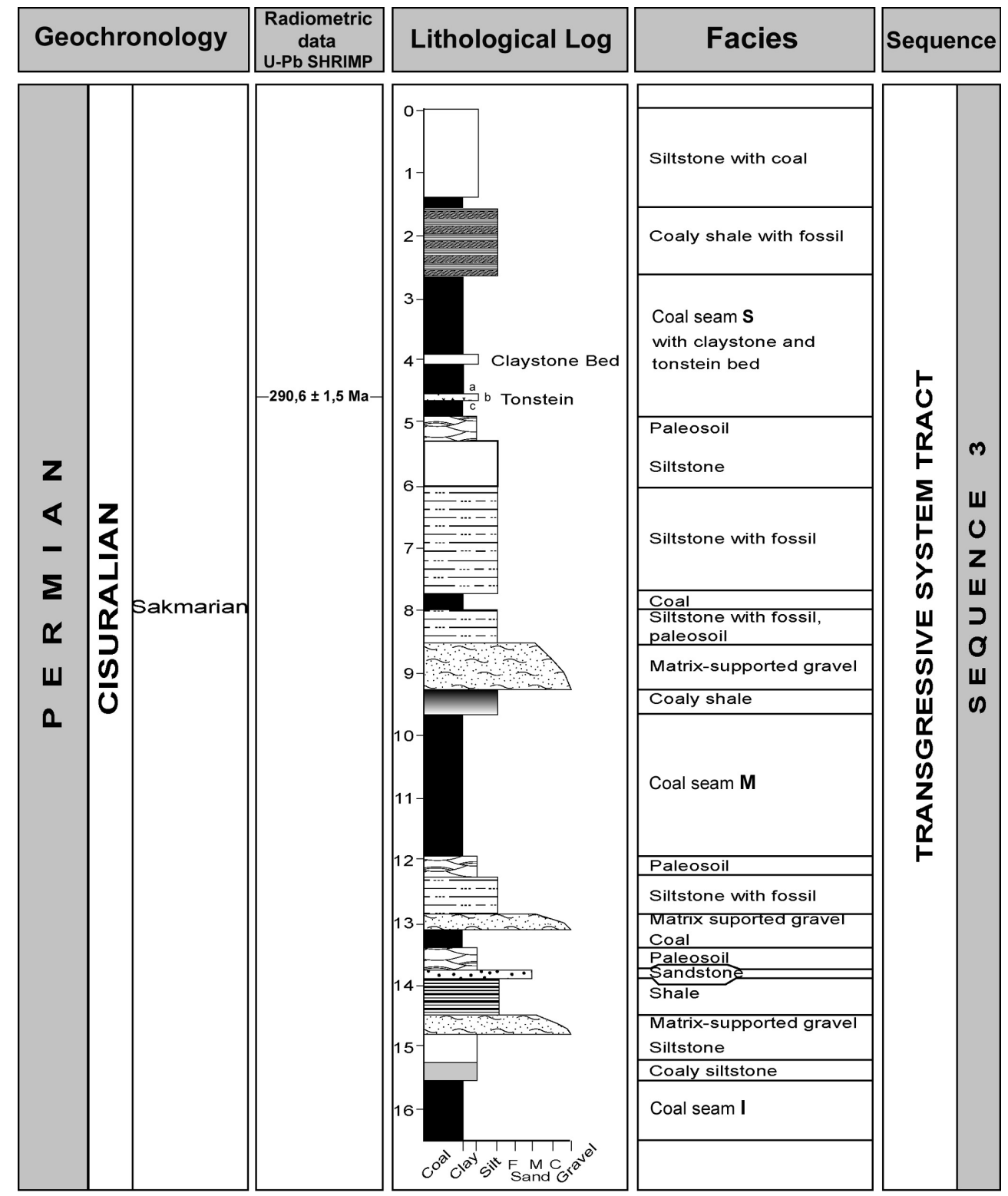

Figure 2. Lithostratigraphy of the Faxinal coal succession, indicating the uppermost coal seam (from Simas et al. 2009) displaying the coal bed above the tonstein (a), tonstein (b) and the coal below the tonstein (c). 
Brazil, although the bissacate pollen grains appear in this case as the most important components in the palynoassemblage $(41 \%)$. Within this group, the dominant forms are Scheuringipollenites, Alisporites and Vesicaspora reflecting, according to Gould \& Delevoryas (1977), a conspicuous presence of glossopterids in the peat-forming plant community. These taxa are followed by some monosaccate pollen grains with botanical affinity to Cordaites, such as Cannanoropollis and Plicatipollenites (9\%) and striate pollen grains (e.g. Protohaploxypinus and Vittatina) comprising approximately $6 \%$ ), indicating that the conifers were also significant constituents of the original plant community (Balme, 1995; Quadros et al., 1995). Algae-like elements, commonly found in other coal palynofloras (Cazzulo-Klepzig, 2001), are represented mainly by Portalites, Maculatasporites and Tetraporina (5\%). Rare fragments of the alga Botryococcus were identified (less than 1\%) together with the algae-like forms and spores derived from the terrestrial material.

Features of the environment could be interpreted from known ecological preferences of particular plant groups.
According to DiMichele \& Phillips (1994), this paleoflora with a dominance of lycopsids, ferns and sphenopsids, occurring in varying proportions together with common algal forms characterize a hypautochthonous flora developed in lowland areas surrounding the paleomire. This flooding environment propitiated the development of shrub-like vegetation (herbaceous lycopsids, filicopsids and sphenopsids) as well as tree lycopsids due to their specialized growth and reproductive strategies (DiMichele \& Phillips, 1994). Poorly preserved and less abundant pollen grains of arborescent plants (glossopterids, Cordaites and conifers), suggest that, since they are produced by these plants that flourished in mesophylous and xerophylous environments, they were probably transported to the mire over a short distance. These results confirm previous information by Guerra-Sommer et al. (1984) and Dias \& Guerra-Sommer (1994) about the presence of pteridophytic spores together with poorly preserved pollen grains related to glossopterids and Cordaites. Some of the most important palynological forms are illustrated in Figures 3A-I and 4A-I.
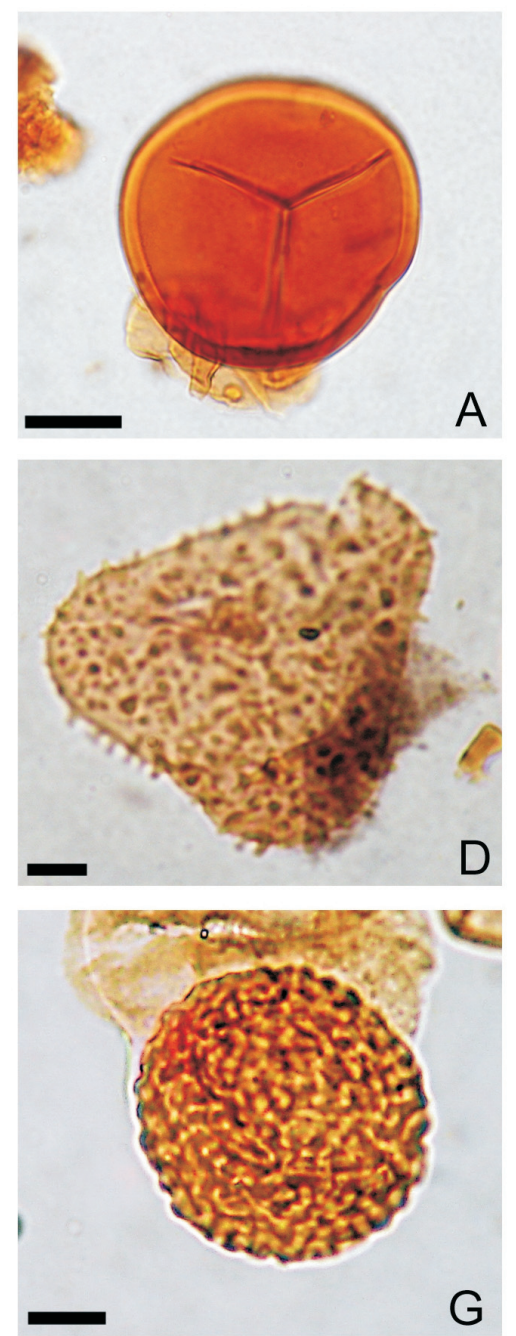

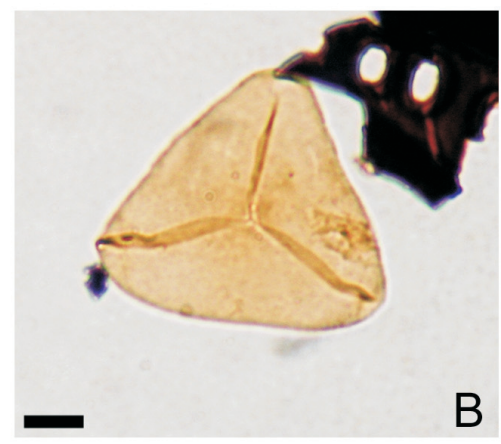

B
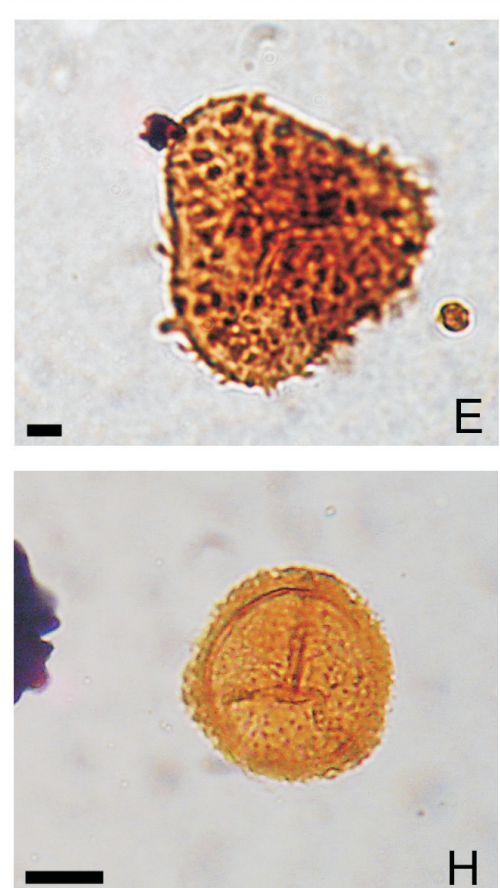
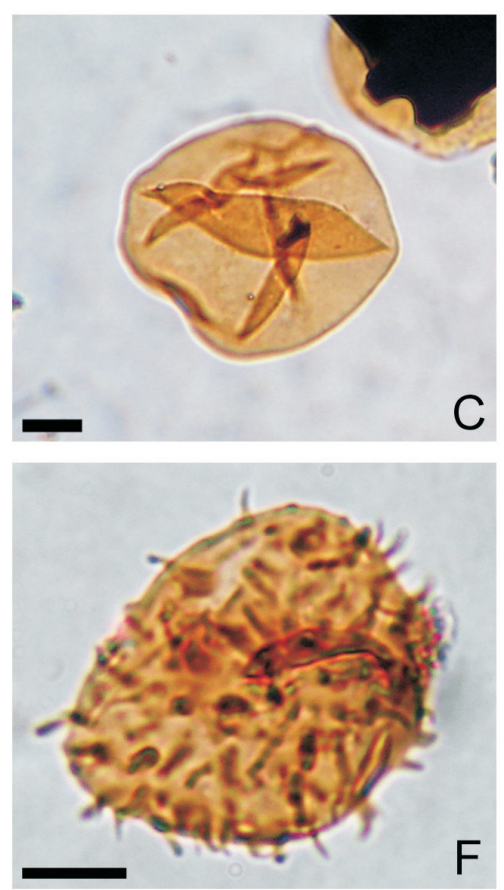

$\mathrm{F}$

Figure 3. A, Punctatisporites gretensis forma minor Hart, 196504978 9.2/109.0; B, Leiotriletes virkii Tiwari, 1965 4978 12.0/95.2; C, Calamospora minuta Bharadwaj, 1967; D, Lophotriletes rectus Bharadwaj \& Salujha, 19634978 9.7/120.0; E, Horriditriletes sp. 4244 30.3/ 90.0; F, Horriditriletes cf. H. ramosus (Balme \& Hennely) Bharadwaj \& Salujha, 19644325 12.4/104.0; G, Convolutispora candiotensis Ybert, 19754301 32.1/100; H, Lundbladispora braziliensis (Pant \& Srivastava) Marques-Toigo \& Picarelli, 1984 4301 3.9/108.0; I, Kraeuselisporites sp. 4325 7.8/80.5. Scale bars $=20 \mu \mathrm{m}$. 
Palynofacies. The organic components in this coal have been grouped in continental organic matter. The sample contains a high relative abundance of the phytoclast group, and this fraction is represented mainly by well-preserved stripped phytoclasts. Besides, well-preserved tracheid tissues as well as lath and equant-shaped black particles were observed. The palynomorphs constitute only an insignificant part of particulate organic matter and are represented mainly by dominant trilete spores and bissacate pollen grains. Algal fragments were also identified (Figure 9).

\section{Tonstein}

Palynology and paleobotany. Results from palynological studies revealed the presence of scarce and poorly preserved material, identified mainly in the basal level. A scarce presence of monosaccate and bisaccate pollen grains (Cannanoropollis and Scheuringipollenites) was noted, comprising approximately $33 \%$ of the whole assemblage, which were found together with some forms of Protohaploxypinus (8\%), all of them showing botanical affinity with Cordaites, glossopterids and conifers. Poorly preserved trilete spores $(9 \%)$ reflect the weak presence of Pteridophyta in the original plant community. Only spores of lycopsids (Lundbladispora and Vallatisporites) and filicopsids (Punctatisporites and Granulatisporites) were identified. Although the palynological material is poorly preserved, a few poorly preserved tetrads of Lundbladispora could be recognized (5\%). Scarce fragments of the colonial alga Botryococcus were identified (less than 2\%), as well as scarce algae-like elements belonging to the genus Portalites (less than 2\%). Other palynological constituents were unidentifiable. The palynoassemblage reflects a plant community dominated
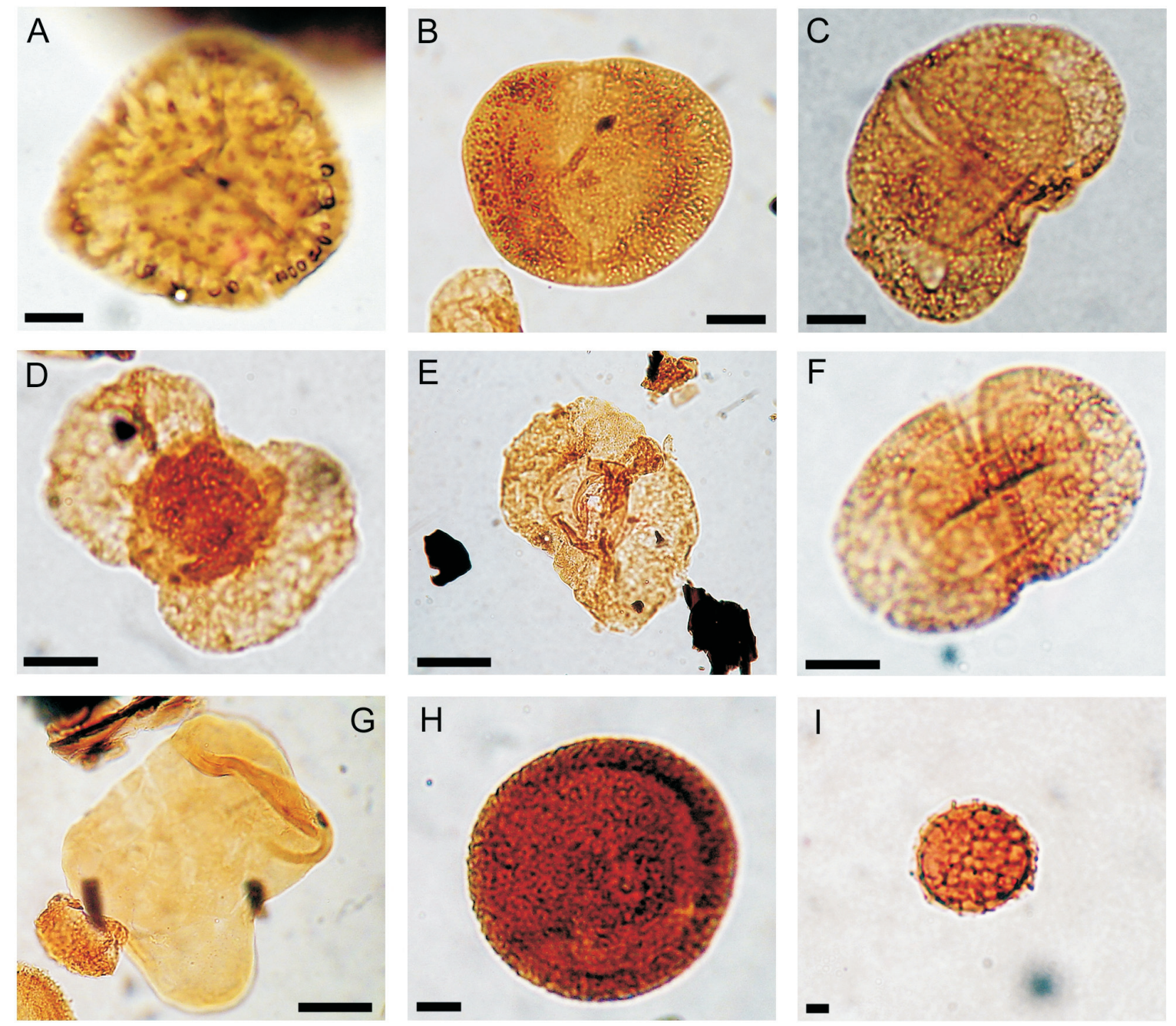

Figure 4. A, Vallatisporites arcuatus (Marques-Toigo) Archangelsky \& Gamerro, 19794244 29.3/105; B, Alisporites splendens (Leschik) Foster, 19754243 9.9/109.8; C, Vesicaspora wilsonii (Schemel) Wilson \& Venkatachala, 1963 4304 10.8/96.0; D, Caheniasaccites ovatus( Bose \& Kar) Archangelsky \& Gamerro, 19794304 28.8/100.5; E, Plicatipollenites cf. trigonalis Lele, 1964 4301 28.6/100.5; F, Protohaploxypinus sp. 4301 8.9/107.0; G, Tetraporina tetragona(Tiwari \& Navale) Kar \& Bose, 19764301 22.4/98.0; H, Portalites gondwanensis Nahuys, Alpern \& Ybert, 19683295 13.0/90.0; I, Maculatasporites gondwanensis Tiwari, 1964 4325 11.5/98. Scale bars $=20 \mu \mathrm{m}$. 
by gymnosperms (Cordaites, glossopterids and conifers), probably formed in a forest swamp in a habitat with periods of standing water (Teichmuller, 1962), as suggested by the presence of tetrads from arborescent lycopsids together with algal forms such as Portalites (Figures 5A-E).

In contrast to the poorly preserved palynological material, previous paleobotanical analyses of this tonstein recognized the presence of an important coalified adpressed flora characterized by the dominance of gymnospermic forms (Guerra-Sommer, 1988; Guerra-Sommer, 1992; Dias \& GuerraSommer, 1984). Foliar fragments related to glossopterids are dominant ( $70 \%$ of the whole association), often preserved as foliar tufts (Figure 6), and unattached reproductive structures were identified. Leaves of Cordaites were also identified as well as small fronds of sphenopterids. Furthermore, well-preserved cuticular fragments and dispersed woody fragments are also abundant in the tonstein and confirm the dominance of glossopterids and Cordaites. In the basal levels of this tonstein, the fossil plant assemblage is composed mainly of elements representing the canopy (glossopterids, Cordaites and conifers), while understorey forms (small fronds) were identified in the upper levels. The presence of dispersed woody fragments showing uni- and pluriserial tracheids as well as small and wellpreserved epidermal cuticles related to glossopterids was also observed. Among the epidermal debris, fragments of elongate and square cells with central papillae compose the most frequent group (Figure 5). Fragments of charcoal were recently identified by Jasper et al. (2009), which indicates the occurrence of paleowildfires in this level.

Palynofacies. Palynofacies analyses of the kerogens from different parts of the tonstein layer were conducted by Simas (2008) and indicated high percentages of phytoclasts
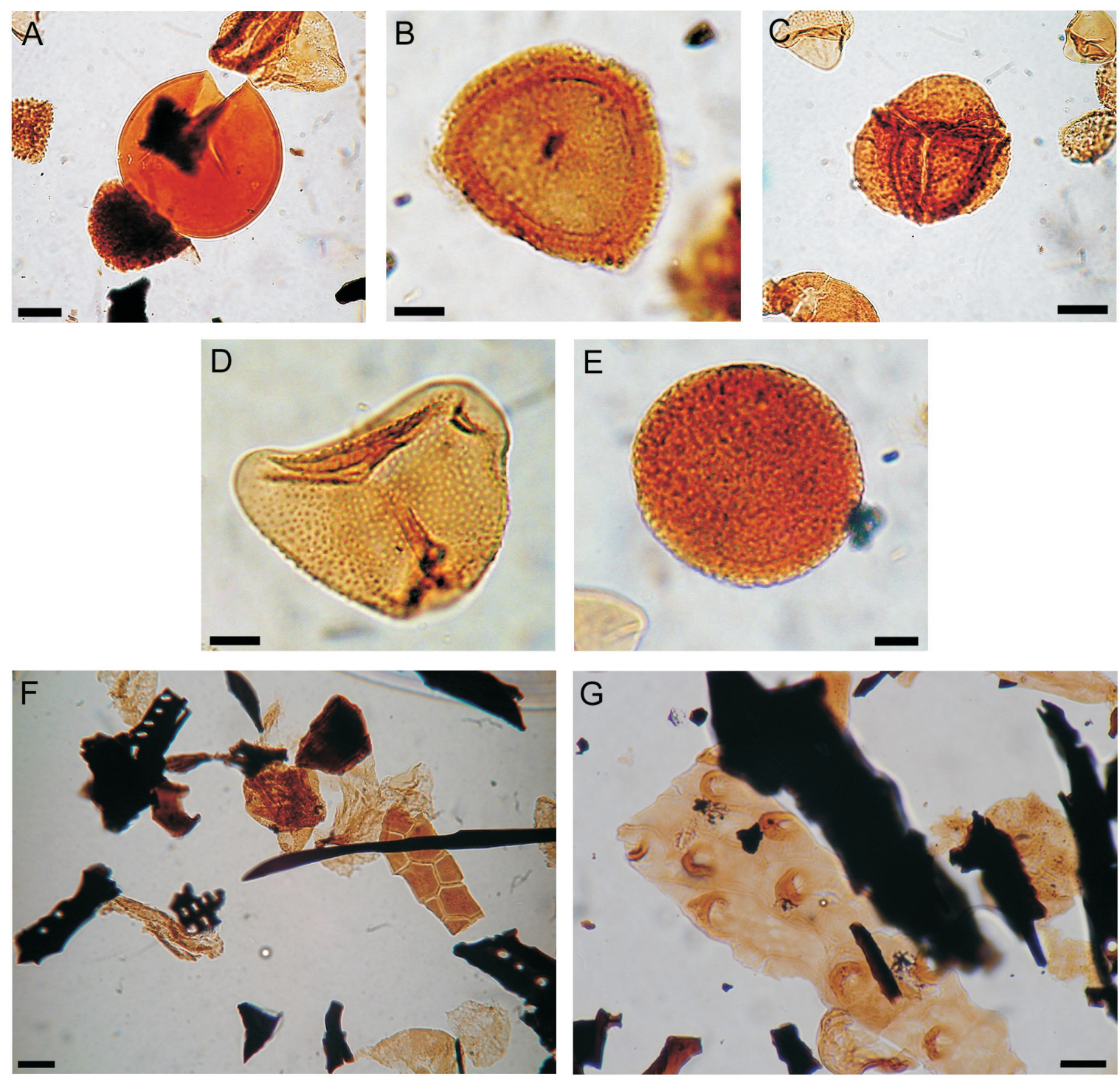

Figure 5. A, Punctatisporites sp. 21603293 1.5/107.0; B, Lundbladispora braziliensis (Pant \& Srivastava) Marques-Toigo \& Picarelli, 19843293 33.2/97.0; C, Tetrad of Lundbladispora sp. 3924 32.0/102.0; D, Granulatisporites micronodosus Balme \& Hennelly, 19563293 22.0/103.5; E, Portalites gondwanensis Nahuys, Alpern \& Ybert, 19683293 12.0/98.0; F, general view of fragmented tracheids and epidermal cuticles; $\mathbf{G}$, fragment of epidermal cuticle showing cells with papillae. Scale bars $=20 \mu \mathrm{m}$. 
combined with low palynomorph content. Microstratigraphic analyses revealed the presence of hundreds of amalgamated sporomorphs at the base level and the presence of algal colonies of Botryococcus at the top level (Figure 10). Special environmental conditions have been inferred from the preservation type, which is linked to a rapid saturation and precipitation of palynomorphs, associated with a subaqueous deposition of the bed. This evidence challenged the hypothesis of a detrital input for the structured organic matter and pointed to a rapid burial process. Thus, the hypothesis of volcanic air fall deposition corroborates the palynofacies results.

The preservation of Botryococcus colonies at the top of the tonstein layer demonstrated the subaqueous deposition of the bed (Traverse, 1955). Although palynological analyses performed on the tonstein showed scarce fragments of this alga, in contrast to the results obtained in palynofacies studies, it is important to remark that, according to Batten \& Grenfell (1996), fossil Botryococcus colonies are usually insufficiently translucent for satisfactory study in transmitted light. Their structure is often more clearly revealed if they are subjected to blue light or ultraviolet irradiation, because like other palynomorphs they have a high lipid content and the surface details are brought into relief as they strongly respond to fluorescence (Figures 10E-F).

The brown color of several cuticle fragments and tracheids was linked to thermal alteration.

\section{Coal bed above the tonstein}

Palynology. Palynological analyses on this coal provided results very similar to those obtained preliminarily by Guerra-Sommer et al. (1984) and Cazzulo-Klepzig et al. (2007). Bisaccate pollen grains are the most important group in the palynoassemblages. The dominance of forms of Scheuringipollenites, Vesicaspora and Alisporites is reflected by their identification as $57 \%$ of the palynoassemblage and point out the significance of glossopterids in the peat coal-forming vegetation. The presence of Cordaites is indicated by monosaccate pollen grains mainly of the genus Plicatipollenites (11\%). Forms of Protohaploxypinus, Complexisporites and Vittatina, that are recorded in similar proportion to the monosacate and bissacate pollen grains $(12 \%)$, reflect the presence of conifers in the peat-forming flora. Contrary to the majority of coal palynofloras identified in the southernmost Brazilian Gondwana, including the palynoflora identified in the coal bed below the tonstein, trilete spores of

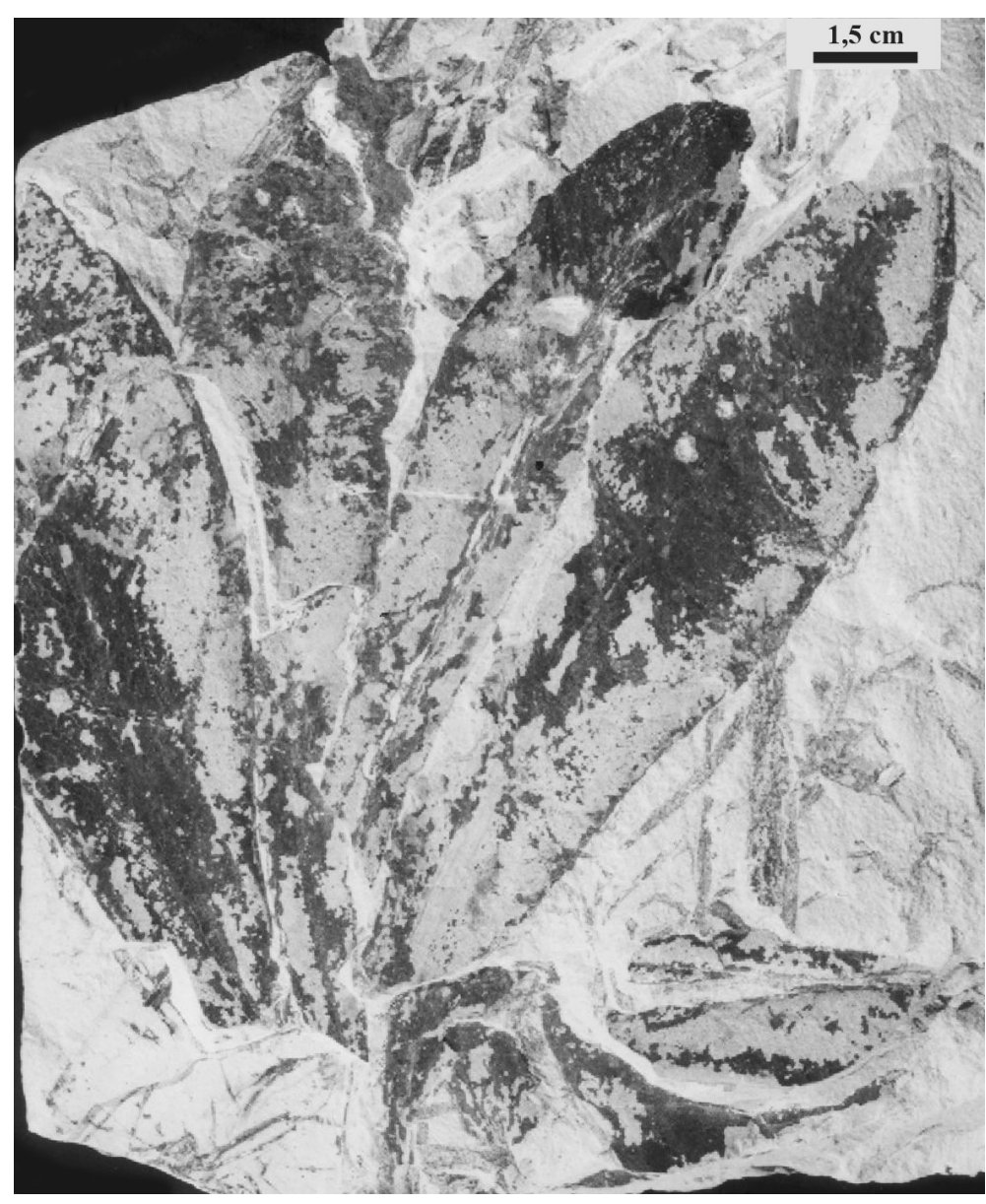

Figure 6. Foliar tuft of Glossopteris papillosa Guerra-Sommer, 1992. 
Peridophyta, commonly found in the coals, are sub-dominant in this palynoassemblage ( approximately $18 \%$ of the trilete group). Lundbladispora is the most important genus (11\%), representing arborescent lycopsids. Leiotriletes, Lophotriletes, Horriditriletes, Convolutispora, Punctatisporites and Calamospora (filicopsids) are less common in the palynoassemblage $(8 \%)$. These compositional peculiarities demonstrate that this coal palynoflora was derived from a more diverse plant community than those recorded for other South Brazilian coals, mainly in quantitative terms. The peculiarity of the palynofloristic composition may be confirmed mainly considering the scarcity of algae-like elements. Portalites and Maculatasporites are the only elements of this group (1\%). Scarce and very fragmented colonies of Botryococcus were identified. The most important palynological forms are shown in Figures 7A-L and 8A-F.
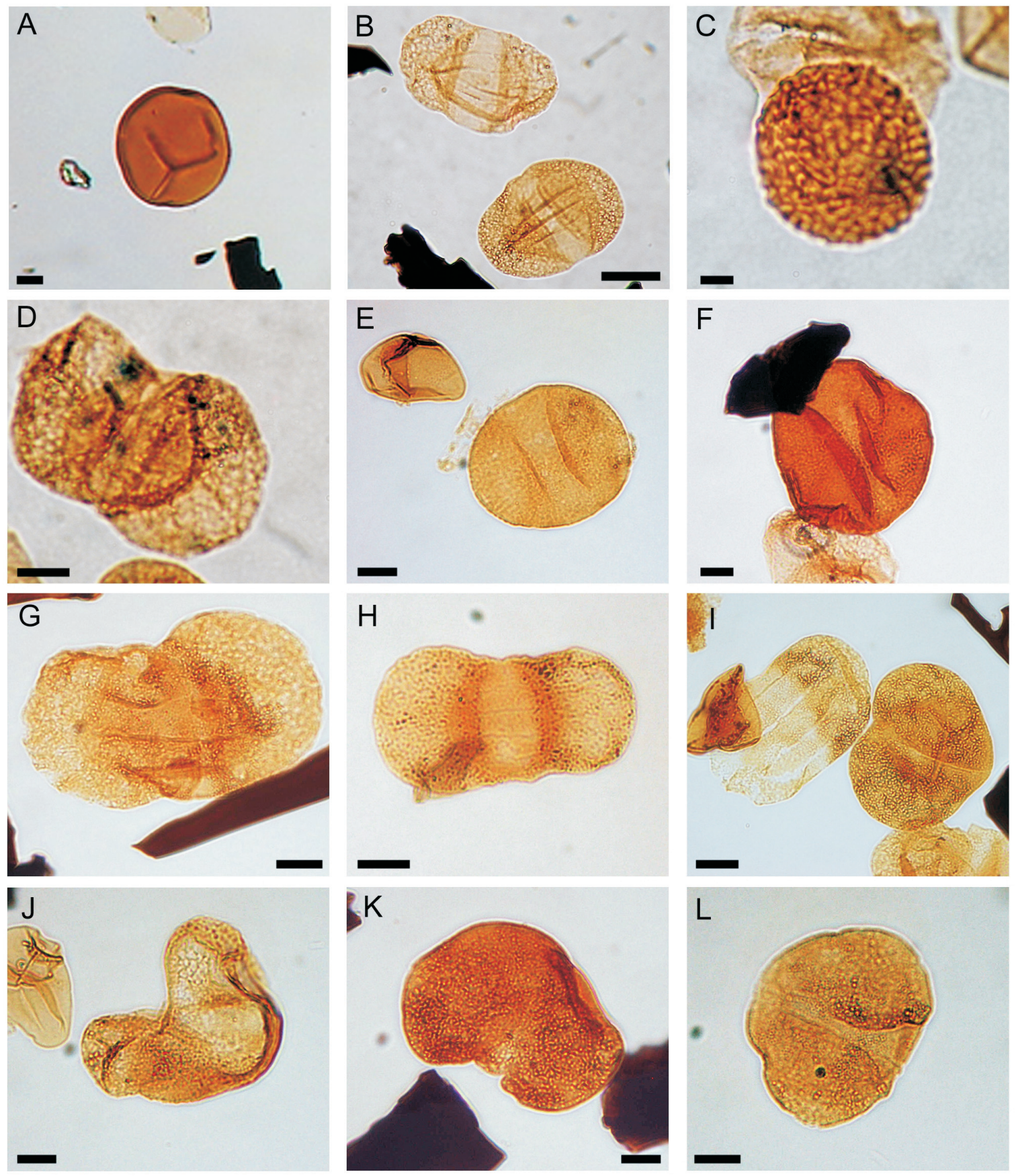

Figure 7. A, Retusotriletes simplex Naumova, 19634985 8.0/97.0; B, Protohaploxypinus sp. 4980 11.8/109.0; C, Convolutispora candiotensis Ybert, 197549809 .0/97.6; D, Lunatisporites cf. L. variesectus Archangelsky \& Gamerro, 1979 4985 12.2/95.0; E, Alisporites sp. 4984 10.0/107.0 and Protohaploxypinus sp. 4980 1.8/109.0; F, K, Scheuringipollenites ovatus (Balme \& Hennely) Foster, 19754980 6.0/104.0; G, Protohaploxypinus cf. P. hartii Foster, 1979 4982; H, Protohaploxypinus sp. 4980 9.2/104.0; la. Complexisporites polymorphus Jizba, 1962; Ib. Vesicaspora ovata 4983 7.0/105.0; J, K, L, Vesicaspora wilsonii (Schemel) Wilson \& Venkatachala, 1963 4984 10.8/94.0. Scale bars $=20 \mu \mathrm{m}$. 

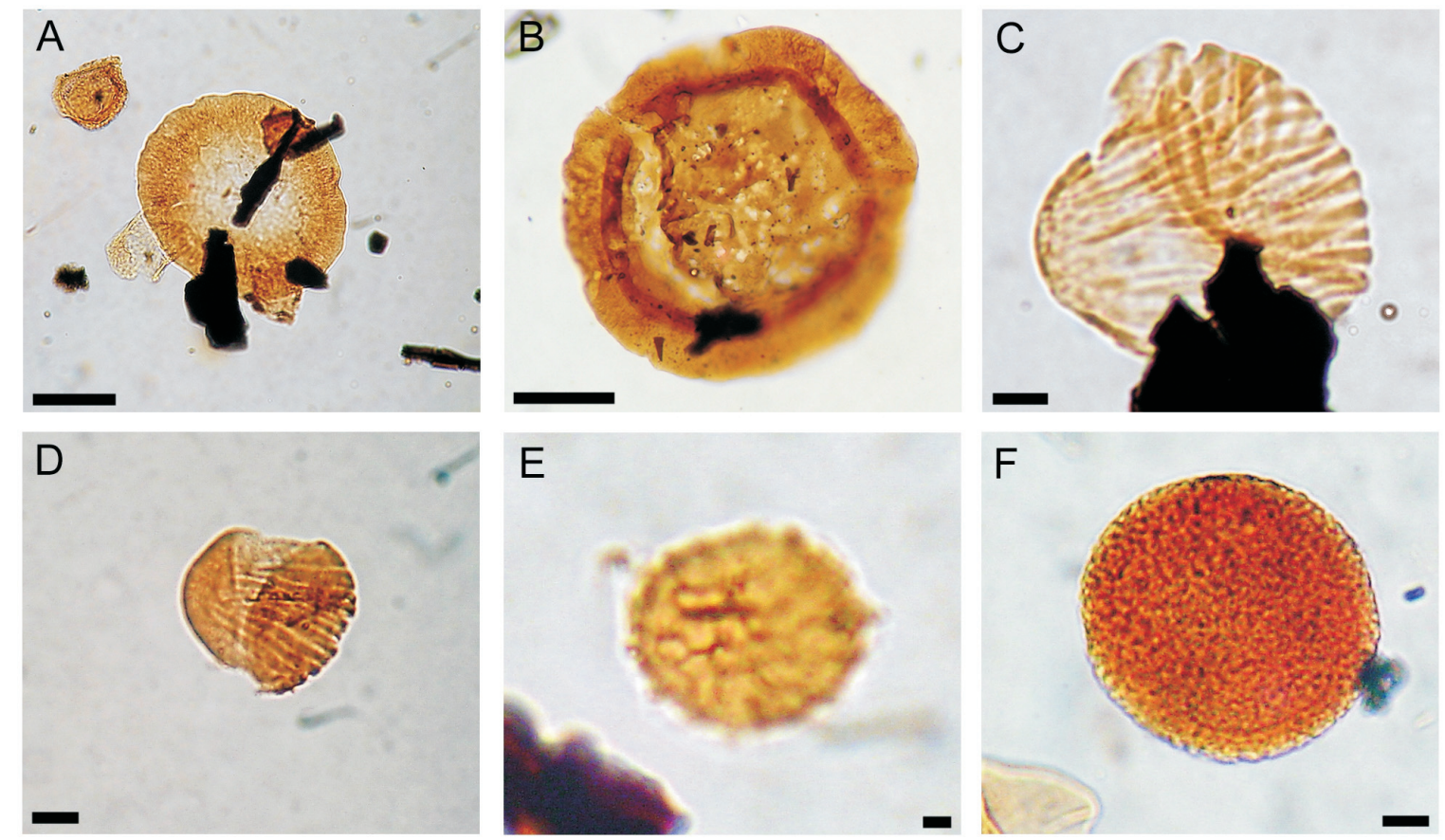

Figure 8. A, Cannanoropollis sp. 4985 9.1/114.0; B, Plicatipollenites gondwanensis (Balme \& Hennelly) Lele, 1964 4980 6.8/105.0; C, Vittatina sp. 4980 5,0/124,0; D, Vittatina sp. 4980 11.9/123.0; E, Maculatasporites gondwanensis Tiwari, 1964 4983 12.0/108.6; F, Portalites gondwanensis Nahuys, Alpern \& Ybert, 19684980 9.9/114.0. Scale bars $=20 \mu \mathrm{m}$.

The dominance of subarborescent/arborescent vegetation suggests a development in a forest swamp, probably in a small distant marginal part of the mire. Similar results obtained in palynological studies which have demonstrated the dominance of pollen grains produced by pteridosperms in the palynoflora were confirmed through cuticular analyses. Abundant dispersed woody fragments (mainly tracheids) which occurred oxidized may be related to pteridosperms. Likewise, better-preserved pieces of cuticles found together with the dispersed wood fragments correspond to pteridosperms, mainly to glossopterids and Cordaites, pointing out the significant presence of these plants in the peat-forming vegetation. Dispersed pteridophytic remains are subdominant and fragmented, confirming the same characteristics shown by the palynological content.

Palynofacies. In this sample, the terrestrial organic components have, in qualitative terms, a similar composition compared to the sample from the coal bed below the tonstein; however, the relative frequency differs between them. The percentage of sporomorphs is very low, and bissacate and striate pollen grains are dominant. Fragments of Botryococcus are less common. The phytoclasts are dominated either by opaque phytoclasts and thick cuticular layer fragments associated with the innermost part of the epiderm (Figures $9 \mathrm{H}, \mathrm{L})$. This thick cuticular debris could indicate that the land plant fragments came from leaves. Cuticular fragments showed a dark-orange fluorescence, suggesting an oxidation process that occurred as an alteration in water column due to the process of ash-fall deposition.

\section{FINAL REMARKS}

Palynological studies on the uppermost Coal Seam S in the Faxinal coalfield demonstrate that three fossil floras may be distinguished. The first, corresponding to the coal bed below the tonstein, is indicated by the miospore assemblage giving evidence, as a whole, of a parent plant association composed dominantly of herbaceous and arborescent lycopsids, Calamites and ferns, with low occurrence of gymnosperms. Algae-like elements are common and fragments of Botryococcus, although scarce, were identified. This megaflora displays a composition very similar to that of the hypautochthonous peat-forming vegetation recorded in the majority of southernmost Brazilian coal-forming floras. In the peat coal-forming environment, the vegetation, composed predominantly of shrub-like vegetation and algal elements, was growing on the peat swamp and surrounding areas when the ash-fall occurred and interrupted peat deposition for a while (Figure 13, stage A ).

The second one, corresponding to the intermediary tonstein level, is represented by well-preserved leaves and reproductive structures of an autochthonous Glossopteris flora, which occur together with fragmentary fronds identified as pteridophylls. A probable selective process of preservation resulted from the differential effect of the ash-fall on this flora growing on the peat. Air fall events generally allow differential survival of organisms and cause less extreme changes in the local ecology. The initial phase of ash- 
fall probably affected the arborescent plants (glossopterids, Cordaites and conifers) representing, in the scenario, the canopy. Leaves and reproductive structures of these plants were drawn to the basal level and deposited by precipitation together with saccate pollen grains and other plant remains (Figure 13, stage B). At the final phase (top of the tonstein), with the decrease in the intensity of the process of ash-fall, closing a rapid time interval of deposition, the megafloristic remains are less common with scarce pollen grains. In this stage, the algal content, showing abundant fragments of Botryococcus and other algae-like elements, reflects a subaqueous deposition and the probable reestablishment of favorable conditions for peat accumulation.
The third phase, corresponding to the peat coalforming vegetation which originated the coal bed above the tonstein deposition, is distinct from the plant community which characterized the first stage of peat accumulation (lower coal bed). The palynoflora is dominated by bissacate pollen grains (taeniate or nontaeniate) with botanical affinity with glossopterids, Cordaites and conifers. These elements, found together with dispersed woody fragments, tracheids and epidermal cuticles, represent arborescent plant communities formed in a forest swamp or in a habitat with short periods of standing water. A minor representation of spores from pteridophytic vegetation probably reflects the effect of the ash-fall disturbance hindering pioneer plants from
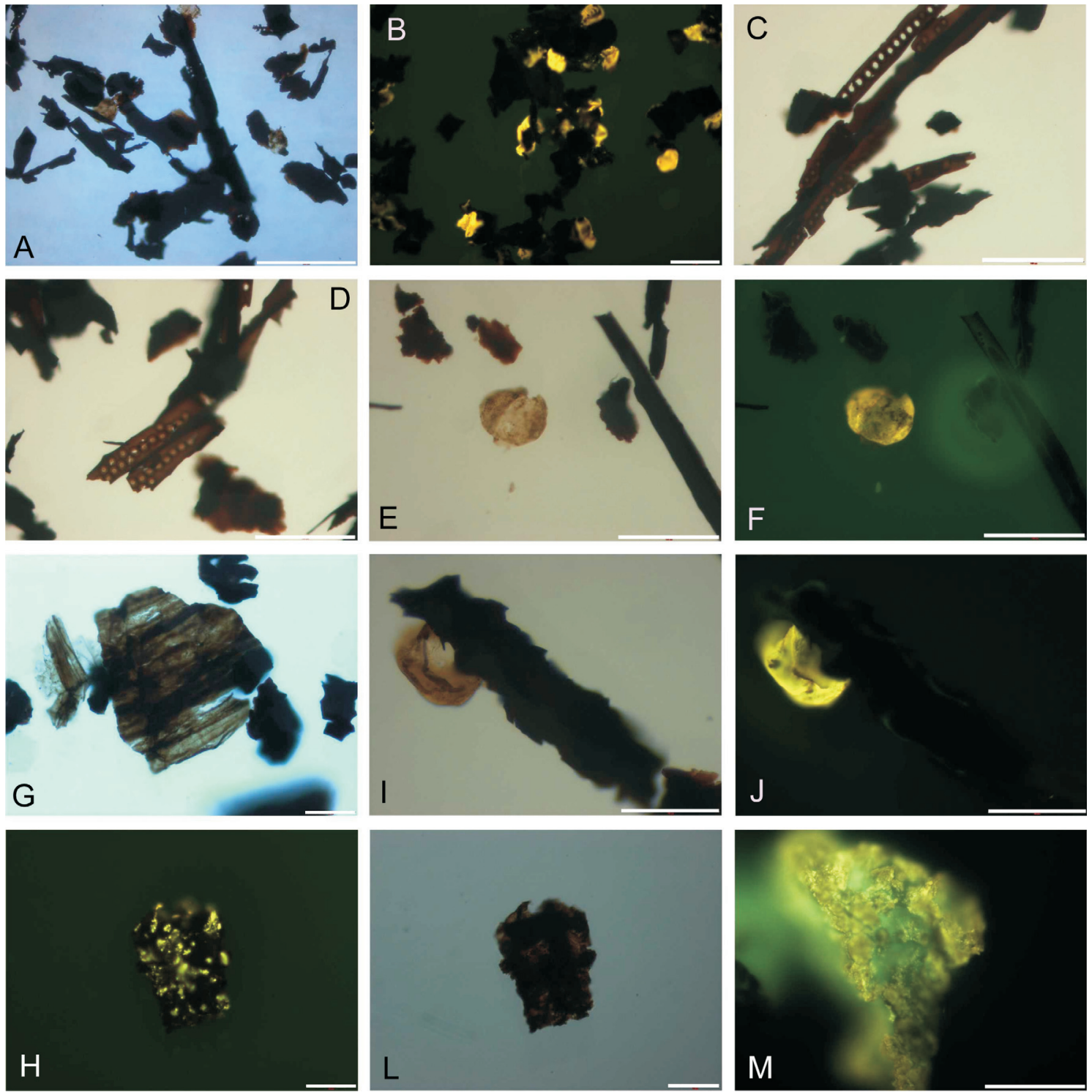

Figure 9. A, B, general view of cuticular fragments, woody tissues and spore; C, D, tracheids of gymnosperm with bordered pits; E, F, bissacate pollen grain; $\mathbf{G}$, fragment of parenchyma; $\mathbf{H}$, L, fragment of coal; I, J, fragment of tracheids and bissacate pollen grain; $\mathbf{M}$, amorphous organic matter. Figures A, C, D, E, G, I, L with transmitted light; B, F, J, H, M with fluorescence. Scale bars: A, B = $200 \mu$ m; C$\mathrm{F}=100 \mu \mathrm{m} ; \mathrm{G}-\mathrm{M}=20 \mu \mathrm{m}$. 

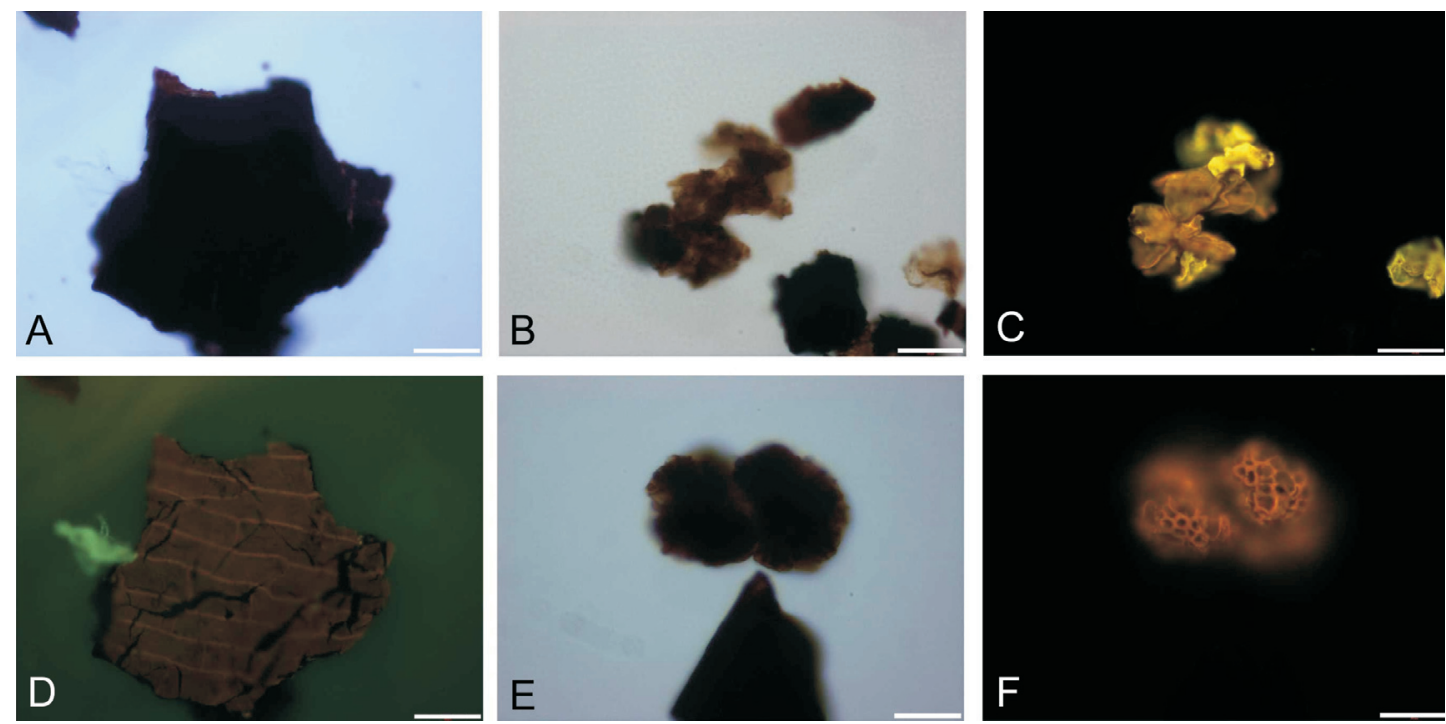

Figure 10. A, D, fragment of upper epidermal cuticle; B, C, amalgamated spores; E, F, degraded and fragmentary colony of Botryococcus. Figures A, B, E with transmitted light; C, D and F with fluorescence. Scale bars $=20 \mu \mathrm{m}$.

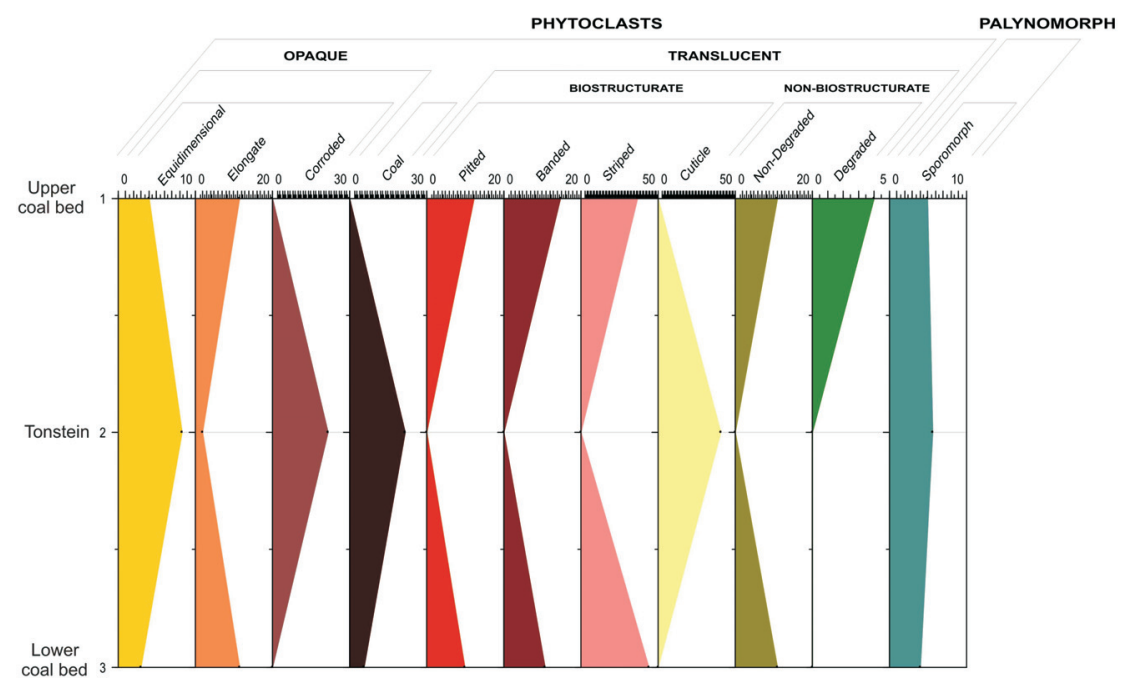

Figure 11. Histogram showing the relative abundance of each component of the phytoclast group in the lower coal bed, tonstein and upper coal bed.

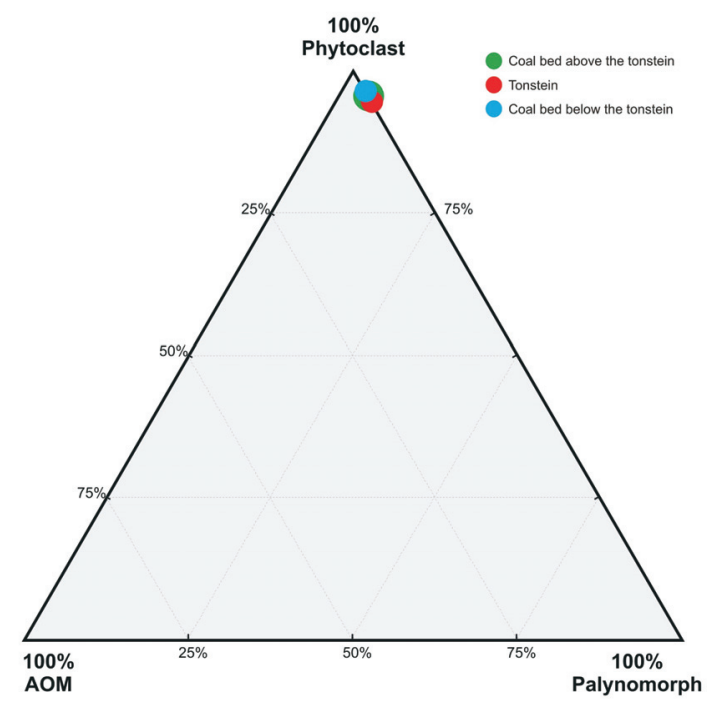

Figure 12. Ternary graphic representing relative frequency of the main constituents of coals and tonstein (phytoclasts, palynomorphs and amorphous organic matter). flourishing in the marginal areas of the mire (Figure 13, stage C).

Thus, this floral succession deposited over a short time interval provides clear evidence of the effect of the ash-fall deposition on the vegetation character. The vegetation most clearly changes across the tonstein level and the coal bed above it. In the tonstein, favorable conditions for organic matter preservation were demonstrated by the well-preserved megafloristic remains as well as by the presence of massive associations of well-preserved amalgamated clusters of sporomorphs through palynofacies analyses. Palynofacies studies were shown to be an important tool for recognizing the paleofloristic evolution as well as paleoecological changes and contributed to the final interpretation. A tentative reconstruction of the floristic evolution in the coal succession is outlined in Figure 13. 


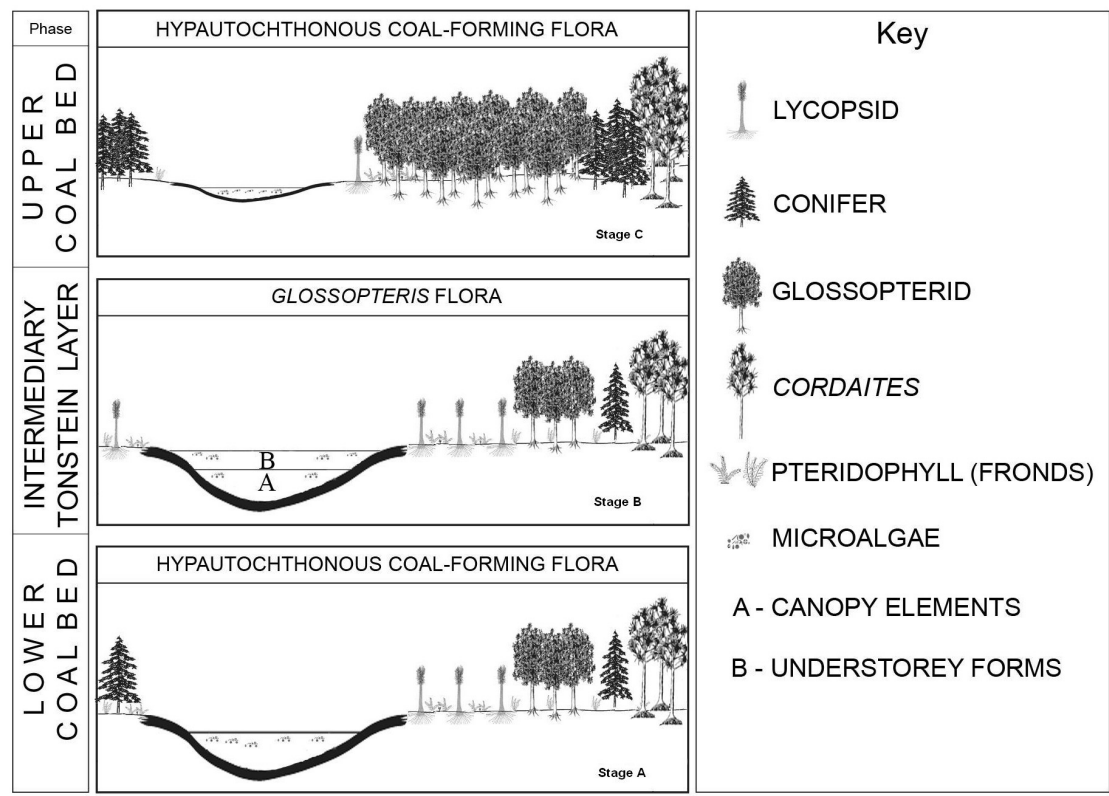

Figure 13. Reconstruction of the floristic evolution of peat-forming plant communities in a coal succession at the Faxinal coalfield. Stage A, representing the hypautochthonous flora composed of herbaceous and arborescent lycopsids, glossopterids, Cordaites and conifers, growing around the mire besides algal elements (filicopsids and sphenopsids not shown in reconstruction). Stage B, representing a compressed flora preserved in tonstein (glossopterids, Cordaites, conifers, pteridophylls, scarce lycopsids; sphenopsids not shown in reconstruction) and algal elements. Stage C, consisting of a peat-forming plant community dominated by arborescent plants (glossopterids, Cordaites and conifers), growing in marginal areas around the mire (coastal mires in inland areas), with lower representation of pioneer vegetation (herbaceous lycopsids and ferns) and scarce algal elements.

\section{ACKNOWLEDGMENTS}

The authors thank Companhia de Pesquisas e Lavras Minerais (COPELMI) for access to the samples and also Conselho Nacional de Desenvolvimento Científico e Tecnológico $(\mathrm{CNPq})$ for the financial support. W.A. DiMichele and A. Jasper provided constructive comments and suggestions which greatly improved the paper.

\section{REFERENCES}

Balme, B.E. 1995. Fossil in situ spores and pollen grains: an annotated catalogue. Review of Palaeobotany and Palynology, 87:81-323.

Batten, D.J. \& Grenfell, H.R. 1986. Green and blue-green algae. Botryococcus. In: J. Jansonius \& D. McGregor (eds.) Palynology: principles and applications. American Association of Stratigraphic Palynologists Foundation, vol. 1, 7d:205-214.

Cazzulo-Klepzig, M. 2001. Significado paleoecológico de alguns palinomorfos ocorrentes nos carvões eopermianos do Rio Grande do Sul, sul do Brasil. Pesquisas, 2:81-97.

Cazzulo-Klepzig, M. 2002. Palinologia aplicada à reconstituição das unidades de paisagem e dinâmica das turfeiras formadoras dos carvões permianos do Rio Grande do Sul, sul do Brasil. Programa de Pós-graduação em Geociências, Universidade Federal do Rio Grande do Sul, Tese de Doutorado, 300 p.

Cazzulo-Klepzig, M.; Guerra-Sommer, M.; Menegat, R.; Simas, M.W. \& Mendonça Filho, J.G. 2007. Peat-forming environment of Permian coal seams from the Faxinal coalfield (Paraná Basin) in Southern Brazil, based on palynology and palaeobotany. Revista Brasileira de Paleontologia, 10(2):117-127.

Combaz, A. 1980. Les kérogens vus au microscope. In: B. Duran (ed.) Kerogen-insoluble organic matter from sedimentary rocks, Edition Technip, p. 55-112.

Creech, M. 2002. Tuffaceous deposition in the Newcastle Coal Measures: challenging existing concepts of peat formation in the Sydney Basin, New South Wales, Australia. International Journal of Coal Geology, 51:185-214.

Crowley, S.S.; Dufek, D.A.; Stanton, R.W. \& Ryert, T.A. 1994. The effects of volcanic ash disturbances on a peat-forming environment: environmental disruption and taphonomic consequences. Palaios, 9:158-174.

De Jenkhowsky, B. 1963. Sur les diverses notions de frequence intéressant l'étude des populations fossiles, spécialement en palynologie. Revue de l'Institut Français du Petrole, 18:868-885.

Dias, M.E. \& Guerra-Sommer, M. 1994. Integração entre dados mega e microflorísticos na Jazida do Faxinal, Rio Grande do Sul: estudos preliminares. Acta Geologica Leopoldensia, 39(1):249-260.

DiMichele, W.A. \& Phillips, T.L. 1994. Palaeobotanical and palaeoecological constraints on models of peat-formation in the Late Carboniferous in Euramerica. Palaeogeography, Palaeoclimatology, Palaeoecology, 106:39-90.

Formoso, M.L.L.; Calarge, L.M.; Garcia, A.J.V.; Alves, D.B.; Gomes, M.E.B \& Mizusaki, A.M. 1999. Permian tonsteins from the Paraná Basin, Rio Grande do Sul, Brazil. Proceedings of the International Clay Conference, 11:613-621.

Gastaldo, R.A. 1994. The genesis and sedimentation of phytoclasts with examples from coastal environments In: A. Traverse (ed.) Sedimentation of organic particles, Cambridge University Press, p. 103-127.

Glasspool, I.J. 2003. Hypautochthonous-allochthonous coal deposition in the Permian, South African, Witbank Basin no.2 seam: a combined approach using sedimentology, coal petrology and palaeontology. International Journal of Coal Geology, 53:81-135. 
Gould, R.E. \& Delevoryas, J. 1977. The biology of Glossopteris: evidence from petrified seed-bearing and pollen-bearing organes. Alcheringa, 1:1387-99.

Guerra-Sommer, M. 1988. Padrões epidérmicos da Flora Glossopteris na Jazida do Faxinal (Formação Rio Bonito, Kunguriano, RS): implicações taxonômicas, bioestratigráficas e paleogeográficas. Programa de Pós-Graduação em Geociências, Universidade Federal do Rio Grande do Sul, Tese de Doutorado, $751 \mathrm{p}$.

Guerra-Sommer, M. 1992. Padrões epidérmicos de glossopteridales da Tafoflora do Faxinal (Formação Rio Bonito, ArtinskianoKunguriano, Bacia do Paraná, Brasil). Pesquisas, 19:26-40.

Guerra-Sommer, M.; Cazzulo-Klepzig, M.; Santos, I.O.; Hartmann, L.A.; Ketzer, J.M.F. \& Formoso, M.L.L. 2008b. Radiometric age determination of tonsteins and stratigraphic constraints for the Lower Permian coal succession in southern Paraná Basin, Brazil. International Journal of Coal Geology, 74:13-27.

Guerra-Sommer, M.; Cazzulo-Klepzig, M.; Formoso, M.L.L.; Menegat, R. \& Mendonça Filho, J.G. 2008c. U-Pb dating of tonstein layers from a coal succession of the southern Paraná Basin (Brazil): a new geochronological approach. Gondwana Research, 14:474-482.

Guerra-Sommer, M.; Cazzulo-Klepzig, M.; Menegat, R.; Formoso, M.L.L.; Basei, A.M.S.; Barboza, E.G. \& Simas, M.W. 2008a. Geochronological data from the Faxinal coal succession, southern Paraná Basin, Brazil: a preliminary approach combining radiometric $\mathrm{U}-\mathrm{Pb}$ dating and palynostratigraphy. Journal of South American Earth Sciences, 25(2):246-256.

Guerra-Sommer, M.; Marques-Toigo, M. \& Corrêa da Silva, Z.C. 1991. Original biomass and coal depositional environment in Southern Brazil, Lower Permian, Paraná Basin. Bulletin de Societé Géologique de France, 62:227-237.

Guerra-Sommer, M.; Marques-Toigo, M.; Paim, P.S.G.; Henz, G.I.; Silveira, J.B.R. \& Backeuser,Y. 1984. Estudo microflorístico e petrológico dos carvões da Mina do Faxinal, Formação Rio Bonito (Permiano), RS. Boletim do Instituto de Geociências do USP, 15:73-83.

Guerra-Sommer, M.; Santos, J.O.S.; Cazzulo-Klepzig, M.; Hartmann, L.A.; Menegat, R. \& McNaughton, N.J. 2006. The geochronological significance of tonstein in coal-bearing strata from the southern Paraná Basin. In: SOUTH AMERICAN SYMPOSIUM ON ISOTOPE GEOLOGY, 5, 2006. Short Papers, Punta del Este, p. 254-257.

Henz, G.I. 1986. Organopetrologia e organogeoquímica dos carvões da Jazida do Faxinal, Município de Arroio dos Ratos, RS, Brasil. Programa de Pós-Graduação em Geociências, Universidade Federal do Rio Grande do Sul, Dissertação de Mestrado, $158 \mathrm{p}$.

Holz, M. 1998. The Eopermian coal seams of the Paraná Basin in southernmost Brazil: an analysis of the depositional conditions using sequence stratigraphy concepts. International Journal of Coal Geology, 36:141-163.

Holz, M.; Kalkreuth, W. \& Banerjee, I. 2002. Sequence stratigraphy of paralic coal-bearing strata: an overview. International Journal of Coal Geology, 48:147-179.

Holz, M.; Kuchle, J.; Phillip, R.; Bischoff, A.P. \& Arima, N. 2006. Hierarchy of tectonic control on stratigraphic signatures: baselevel changes during the Early Permian in the Paraná Basin, southernmost Brazil. Journal of South American Earth Science, 22:185-304.

Holz, M.; Vieira, P.E. \& Kalkreuth, W. 2000. The Early Permian coal-bearing succession of the Paraná Basin in southernmost
Brazil: depositional model and sequence stratigraphy. Revista Brasileira de Geociências, 30:420-422.

Hudle, J.W. \& Englund, K.J. 1966. Geology of coal reserves of the Kermitt and Varney areas, Kentucky, USA. Geological Survey Professional Paper, 507:1-83.

Hughes, P.D.M. \& DuMayne-Peaty, L. 2002. Testing theories of mire development using multiple sucession at Crymley Bog, West Galmorgan, South Wales, United Kingdom, Journal of Ecology, 90(3):456-471.

Jasper, A.; Uhl, D.; Machado,T.G.; Gonçalves, L.V.; GuerraSommer, M. \& Cazzulo-Klepzig, M. 2009. Late Paleozoic wildfires in South American part of Gondwana. In: LATEINAMERICAN KOLLOQUIUM (LAKS), 2009. Abstracts, Gottingen, p. 146-147.

Marques-Toigo, M. \& Corrêa da Silva, Z.C. 1984. On the origin of gondwanic south Brazilian coal measures. Comunicações dos Serviços Geológicos de Portugal, 7:151-160.

Matos, S.L.F.; Yamamoto, J.K.; Riccomini, C.; Hachiro, J. \& Tassinari, C.C.G. 2001. Absolute dating of Permian ash-fall in the Rio Bonito Formation, Paraná Basin, Brazil. Gondwana Research, 4(3):421-426.

Mendonça Filho, J.G. 1999. Aplicação de estudos de palinofácies e fácies orgânica em rochas do Paleozóico Superior da bacia do Paraná, sul do Brasil. Programa de Pós-Graduação em Geociências, Universidade Federal do Rio Grande do Sul, Tese de Doutorado, 338 p.

Mendonça Filho, J.G.; Carvalho, M.A. \& Menezes, T.R. 2002. Palinofácies: In: T.L. Dutra (ed.) Técnicas e procedimentos de trabalho com fósseis e formas modernas comparativas, Editora Unisinos, p. 20-24.

Menezes, T.R.; Mendonça Filho, J.G.; Araújo, C.V.; Souza, I..V.A.F. \& Mendonça, J.O. 2008. Facies Orgânica: conceitos, métodos e estudos de caso na indústria de petróleo. Revista Brasileira de Geociências, 38(2-suplemento):80-96.

Milani, E.J.; Faccini, U.F.; Scherer, C.M.S.; Araujo, L.M. \& Cupertino, J.A. 1998. Sequence stratigraphic hierarchy of the Paraná Basin (Ordovician to Cretaceous), Southern Brazil. Boletim do Instituto de Geociências da USP, 15(2):125-173.

Nichols, D.J. 1995. The role of palynology in palaeoecological analysis of Tertiary coals. International Journal of Coal Geology, 28(2-4):139-159.

Pfefferkorn, H.W. \& Wang, J. 2007. Early Permian coal-forming floras preserved as compressions from the Wuda District (Inner Mongolia, China). International Journal of Coal Geology, 69:90102.

Quadros, L.P.; Marques-Toigo, M. \& Cazzulo-Klepzig, M. 1995. Catálogo de esporos e pólen fósseis do Paleozóico. Boletim de Geociências da Petrobrás, 9(1):1-151.

Ribeiro, G.V.B.; Freitas, J.T.R. \& Souza, R. 1987. Correlação entre três bacias carboníferas do Paleovale Leão-Mariana-Pimentel (RS). In: SIMPÓSIO SUL-BRASILEIRO DE GEOLOGIA, 3, 1987. Actas, Curitiba, p. 335-350.

Simas, M.W., 2008. Origem vulcânica para o tonstein da jazida do Faxinal (RS): estudos mineralógicos, petrográficos e de palinofácies. Programa de Pós-graduação em Geociências, Universidade Federal do Rio Grande do Sul, Dissertação de Mestrado, $117 \mathrm{p}$.

Staplin, F.L. 1969. Sedimentary organic matter, organic metamorphism and oil and gas occurrences. Bulletin Canadian Petrography Geology, 17:47-66.

Teichmuller, M. 1962. Die Genese der Kohle. In: CONGRÉS INTERNATIONAL DE STRATIGRAPHIE ET GÉOLOGIE 
DU CARBONIFÉRE, 4, 1959. Proceedings, Herrlen, v. 3, p. 699-722.

Traverse, A. 1955. Occurrence of the oil-forming alga Botryococcus in lignites and other Tertiary sediments. Micropaleontology, 1(4):343-350.

Traverse, A. 1994. Sedimentation of organic particles. Cambridge, Cambridge University Press, 544 p.

Tyson, R.V. 1995. Sedimentary organic matter: organic facies and palynofacies. London, Chapman \& Hall, 614 p.

Williams, G.L. 1992. Palynology as a palaeoenvironmental indicator in the Brent Group, Northern, North Sea. In: A.C. Morton; R.S. Haszeldine, R.S.; M.R. Giles \& S. Brown (eds.) Geology of the Brent Group, Geological Society of London, Special Publication, 61:203-212.

Whitaker, M.F. 1984. The usage of palynology in the definition of Troll Field geology. In: OFFSHORE NORTHERN SEAS CONFERENCE AND EXIBITION, 6, 1984. Proceedings, Stavanger, Norsk Petroleumsforening, Paper G6, 44 p.

Received in May, 2009; accepted in October, 2009. 